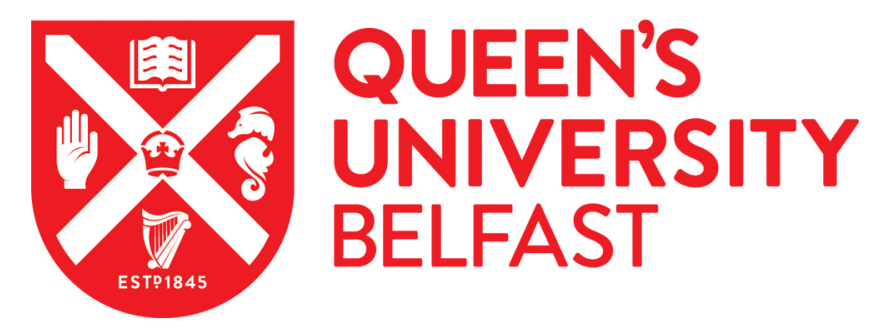

\title{
Monoclonal gammopathy of undetermined significance (MGUS) as viewed by haematology healthcare professionals.
}

McShane, C., Murphy, B., Heng Lim, K., \& Anderson, L. (2017). Monoclonal gammopathy of undetermined significance (MGUS) as viewed by haematology healthcare professionals. European Journal of Haematology. https://doi.org/10.1111/ejh.12962

Published in:

European Journal of Haematology

Document Version:

Peer reviewed version

Queen's University Belfast - Research Portal:

Link to publication record in Queen's University Belfast Research Portal

Publisher rights

Copyright 2017 Wiley This work is made available online in accordance with the publisher's policies. Please refer to any applicable terms of use of the publisher.

\section{General rights}

Copyright for the publications made accessible via the Queen's University Belfast Research Portal is retained by the author(s) and / or other copyright owners and it is a condition of accessing these publications that users recognise and abide by the legal requirements associated with these rights.

Take down policy

The Research Portal is Queen's institutional repository that provides access to Queen's research output. Every effort has been made to ensure that content in the Research Portal does not infringe any person's rights, or applicable UK laws. If you discover content in the Research Portal that you believe breaches copyright or violates any law, please contact openaccess@qub.ac.uk. 
Monoclonal gammopathy of undetermined significance (MGUS) as viewed by haematology healthcare professionals.

Charlene M. McShane ${ }^{1}$, Blain Murphy ${ }^{1}$, Kah Heng Lim² and Lesley A. Anderson ${ }^{1}$.

${ }^{1}$ Cancer Epidemiology and Health Services Research Group, Centre for Public Health, Queen's University Belfast

${ }^{2}$ Centre for Medical Education, School of Medicine, Dentistry \& Biomedical Sciences, Queen's University Belfast

Running title: Healthcare professional views towards MGUS

\section{Corresponding author}

Dr Lesley A Anderson

Lecturer

Centre for Public Health

Queen's University Belfast

Grosvenor Road

Belfast

BT12 6BJ

Tel: 02890632315

Words: $n=2,594$ (main text) $n=198$ (abstract); Number of tables: 2; Number of figures: 0 Number of references:30 


\section{Abstract \\ Objectives}

To investigate the words and descriptions used by haematology healthcare professionals (HCPs) to describe monoclonal gammopathy of undetermined significance (MGUS) to their patients.

\section{Methods}

A cross-sectional survey of haematology HCPs attending an annual haematology conference was undertaken. Content analysis was applied to the returned qualitative responses.

\section{Results}

In total, 55 people, many of whom were doctors $(n=32 ; 58.2 \%)$ responded. The majority of respondents reported using simple terminology such as 'abnormal protein' to describe MGUS to their patients. Some reported using analogies that the patient was more likely to be familiar with, such as comparing a paraprotein to the finding of a mole or lump. Education level, age and cognitive ability were cited as important factors in deciding how and if information was relayed to patients. Many respondents supported frequent follow-up and the transfer of low risk MGUS patients to primary care. However, several highlighted a lack of awareness and understanding of MGUS outside of haematology, particularly within primary care. Only $41.8 \%$ of respondents reported providing all of their patients with an information leaflet.

\section{Conclusions}

With an ageing population, it is important to consider management strategies for MGUS patients.

Our findings will assist those in making these arrangements.

Keywords: MGUS, healthcare professionals, haematology, myeloma, communication aids, management (follow-up) 


\section{KEY FINDINGS \& RECOMMENDATIONS}

- Haematology healthcare professionals often use simplistic terminology to describe MGUS to their patients

- Healthcare professionals require easy access to patient-friendly information leaflets

- Increased support for GPs in diagnosing and following-up MGUS patients may be required and could be supported through the development of guidelines which provide clear instructions on how to manage MGUS patients 


\section{Introduction}

The most prevalent of the plasma cell disorders, monoclonal gammopathy of undetermined significance (MGUS), has been shown in two independent studies to consistently precede multiple myeloma (MM) (1,2), an incurable malignancy (3). Clinically MGUS is defined using the International Myeloma Working Group definition as $<30 \mathrm{~g} / \mathrm{l}$ of serum monoclonal (M) protein in the absence of $\mathrm{MM},<10 \%$ plasma cell infiltration in the bone marrow and absence of end organ damage (CRAB criteria - hypercalcaemia, renal insufficiency, anaemia and bone lesions)(4). The annual risk of progression to $\mathrm{MM}$ and associated malignancies is $0.5-1 \%$, with risk remaining elevated beyond 25 years of observation(5-7). Given the risk of malignant transformation and increased association with medical disorders such as osteoporosis/osteopenia, fractures (particularly vertebral compression fractures), peripheral neuropathy and deep vein thrombosis(8-11) it is recommended that MGUS patients are monitored indefinitely(12).

MGUS is asymptomatic and for the majority of patients, diagnosis will be incidental following routine bloodwork or diagnostic workup. From ongoing research, the study team are aware that the words and descriptions used by patients to describe their MGUS diagnosis vary. This is in line with reports for other pre-malignant conditions, such as ductal carcinoma-in-situ, where patients report diverse terminology used by healthcare professionals including 'breast cancer', 'early cancer', 'in situ', 'premalignant', 'ductal carcinoma in situ', 'DCIS', 'abnormal cells', 'non-invasive' and 'pre-cancer(ous)' (13-15). For patients diagnosed with premalignant conditions, uncertainty about the condition and potential progression to cancer can resonate $(13,16,17)$. For this reason healthcare professionals may choose simpler terminology to describe the condition at the point of diagnosis and follow-up care. How pre-malignant diagnoses are communicated to patients is of paramount importance to reduce the psychosocial impact of diagnosis $(13,18,19)$. Patients with haematological malignancies report varied needs for information on the disease, treatment and prognosis with tailored 
communication to the patient advocated(20). Likewise, provision of accurate and timely information for MGUS patients is equally important. To date, we are unaware of any published literature describing how a diagnosis of MGUS is communicated to patients, the terminology used or the provision of communication aids(21). We report here on the words and descriptions used by haematology healthcare professionals to describe MGUS to their patients and their views towards follow-up.

\section{Methods}

A cross-sectional survey of healthcare professionals attending the annual Haematology Association of Ireland meeting on 14-15 ${ }^{\text {th }}$ October 2016 was undertaken. This meeting is attended by a wide range of specialities interested in haematology including doctors, nurses, allied healthcare professionals, scientists and students from both Northern Ireland (UK) and the Republic of Ireland. Ethical approval from Queen's University Belfast School of Medicine, Dentistry and Biomedical Sciences Research Ethics Committee (Ref: 16.47v1.0) was obtained.

\section{Survey}

The study team developed a short survey consisting of nine questions. Four questions were designed to capture basic information on the respondents' experience with MGUS patients [current job role, region of practice (Northern Ireland vs Republic of Ireland), frequency of seeing MGUS patients and number of MGUS patients on clinic lists]. The remaining questions explored the words and descriptions used by healthcare professionals on the island of Ireland to describe MGUS to their patients. Questions about the use of information leaflets and follow-up recommendations were also included. Each survey was labelled with a unique number and all survey responses were anonymous. 
All attendees were provided with the survey together with the study poster and information booklet within their meeting programme. Only healthcare professionals (doctors, nurses and allied healthcare professionals) were instructed to complete the survey. To increase awareness of the study, the study poster was displayed on the presentation screen at the end of the oral presentation sessions and posters were also displayed throughout the main meeting rooms. Participants were asked to return the completed surveys to the boxes labelled 'MGUS study' located in strategic locations throughout the meeting venue. Respondents were entered into a draw for an iPad mini.

\section{Data Analysis}

The returned survey responses were entered into Microsoft Excel. Analysis was performed in Stata version 14. Chi-square and Fisher's exact tests were used to compare respondent demographics where appropriate. The data was analysed to document the words and descriptions used by healthcare professionals to describe MGUS to their patients. Responses to the open-ended questions were reviewed and analysed using content analysis(22).

\section{Results}

In total, 55 people responded to the survey, Table 1 . Of the 55 respondents, $74.5 \%(n=41)$ worked within the Republic of Ireland, 23.6\% ( $n=13)$ in a United Kingdom region (Northern Ireland) and 1.8\% $(n=1)$ elsewhere. The majority of respondents were doctors $(n=32 ; 58.2 \%)$ with consultant haematologists comprising half of this population $(n=16)$. Of the nursing attendees $(n=21), 57.1 \%$ $(n=12)$ were clinical nurse specialists. There was also one allied healthcare professional. When investigated by region, consultant haematologists were the highest represented group in the Rep. of Ireland (31.7\%) while haematology nurses comprised $46.2 \%$ of the Northern Ireland respondents. The majority of respondents reported diagnosing/following-up/taking care of MGUS patients on a 
weekly basis ( $n=27 ; 49.1 \%$ ). MGUS clinic lists tended to be small consisting of $0-50$ MGUS patients ( $n=23 ; 41.8 \%)$ however, $7.3 \%(n=4)$ of respondents had more than 200 MGUS patients on their clinic lists.

\section{Describing MGUS to patients.}

When asked in an open-ended question, "what words do you use to describe MGUS to patients when first diagnosed?", the majority $(60 \%)$ of respondents favoured simple language such as the presence of an 'abnormal protein in the blood' requiring ongoing monitoring, Table 2 . Only $38.2 \%$ $(n=21)$ of respondents included the terms premalignant, precancer or cancer (example, multiple myeloma, blood/bone marrow cancer or haematological malignancy) within their responses to this question. To aid understanding, some reported using analogies that the patient was more likely to be familiar with such as "like a mole we need to watch" and "finding a paraprotein is a bit like finding a 'lump' and needing to investigate further whether benign or malignant". Signs/symptoms and/or the need to monitor bloods, kidneys and bones for future problems were specifically mentioned by $18.2 \%(n=10)$ respondents. Only $7.3 \%(n=4)$ of respondents, all of whom were doctors $(n=3$ consultants and $n=1$ registrar) reported telling patients of the relationship between MGUS prevalence and advancing age. Overall, respondents were keen to reassure their patients that MGUS was unlikely to cause any harm, but ongoing follow-up/monitoring is needed in case of changes/symptoms requiring treatment.

\section{Telling patients they have MGUS.}

Excluding those $(n=7)$ who stated that informing patients of their diagnosis was not applicable to their job role (specialist nurse/nurse/allied healthcare professional), the majority of respondents (79.2\%; n=38 out of 48) reported telling 'all patients' that they had MGUS using either the term 
'MGUS' or 'monoclonal gammopathy of undetermined/uncertain significance'. An additional $20.8 \%$ $(n=10)$ stated that they only told 'some patients'. While telling patients provided an opportunity for ownership and education, others stated educational level, age and cognitive ability were important factors in deciding how to relay the information, Table 2. Often in these situations, respondents chose to use simpler terms such as 'abnormal protein' to convey the message.

\section{Telling patients of their risk of progression}

In terms of informing patients of their risk of progression to a haematological malignancy, $69.1 \%$ ( $n=38$ out of 55 ) reported telling 'all patients' while $16.4 \%(n=9)$ reported telling only 'some patients'. Respondents who stated 'No' or wrote 'unsure' in response to this question ( $n=8)$, came from nursing/allied healthcare professional backgrounds ( $n=2$ specialist nurses, $n=5$ nurses and $n=1$ allied healthcare professional). One specialist nurse confirmed in free text that they did not tell their patients the risk of myeloma, while the majority felt that communication of risk was the doctor's duty. Those who reported telling 'all patients' were keen to highlight the low risk of progression and referred to published estimates on MGUS progression/risk stratification from the Mayo Clinic studies, Table 2. Others felt that patients needed to be aware of the risk as a rationale for the ongoing monitoring either by their haematology team or GP. The importance of informing patients on risk of progression to myeloma was highlighted by one respondent who said it would be better to do so in case the patient looked MGUS up on the Internet, Table 2. Another respondent stated that they avoid using the terms progression to 'cancer' or 'malignancy' and instead describe progression to a 'blood condition' unless the patient enquires further, in which case progression to 'a type of blood cancer' is discussed. Being elderly/frail were cited as reasons to avoid telling patients of their risk of progression as it was stated that this could cause anxiety or distress to the patient. One respondent stated that risk of progression would only be disclosed to such patients if an increase in 
paraprotein was detected in follow-up. One consultant stated that they told their patients of the risk of progression 'less than I probably should'.

\section{Information leaflet}

Overall, $41.8 \%$ ( $n=23$ out of 55 ) of respondents reported providing all patients with a MGUS information leaflet. An additional $27.3 \%(n=15)$ reported providing an information leaflet if asked by the patient, while $23.6 \%$ ( $n=13$ ) did not give out information leaflets. The majority of nurses $(61.9 \%)$ reported providing information leaflets to all of their patients compared to $31.3 \%$ of doctors, while healthcare professionals in Northern Ireland appeared more likely than those in the Rep. of Ireland to give an information leaflet to all patients (53.8\% vs $39 \%)$. Although no free text option was provided for this question, some respondents provided additional comments stating that some patients declined information leaflets, while others highlighted the lack of appropriate information leaflets and difficulties accessing these resources.

\section{Follow-up}

Excluding the three individuals from nursing backgrounds who earlier in the survey stated that the decision-making process was not part of their job role, more than half of the respondents $(53.8 \%$, $n=28$ out of 52 ) reported that all MGUS patients should be reviewed frequently; $32.7 \%(n=17)$ reported that follow-up should be aimed at patients considered to be at intermediate/high risk of progressing while $25 \%(n=13)$ reported that follow-up should involve primary care. Of the 52 respondents, $78.8 \%$ ( $n=41)$ provided additional information to this question. Many agreed that a combined approach to follow-up was favourable with low risk MGUS patients being followed-up by their GP (if willing) and the intermediate/high risk patients being reviewed frequently by their haematology healthcare team, Table 2. The frequency of follow-up suggested by respondents varied 
with some suggesting that it should be based on risk of progression while others reported followingup patients at varying intervals such as 3-4 months, 6 months or annually. Some felt that follow-up could be nurse-led and via telephone clinics as 'clinic appointments create unnecessary stress to otherwise well patients'. Those advocating for follow-up in primary care suggested that GPs should be supported in this process through the provision of clear instructions on follow-up procedures and the signs and symptoms to look out for.

\section{Awareness of MGUS}

Of the 55 respondents, $29.1 \%$ ( $n=16)$ provided additional comments they believed would be of interest to the study team. The predominant focus of these comments concerned the lack of awareness and understanding of MGUS by healthcare professionals outside haematology which was described as being 'generally poor'. Particular reference was made to GPs who were highlighted as needing support to avoid over-diagnosing and over-referring patients to haematology with abnormal serum protein electrophoresis results. Recognising detection of a paraprotein can 'cause unnecessary anxiety', it was suggested that guidelines are needed to assist healthcare professionals in deciding the appropriate time to test for paraproteins. Similarly, it was highlighted that MGUS patients are often not well-informed and can find it difficult to comprehend MGUS, 'often as much as I try to explain they still don't understand.' As with other patients on watch and wait surveillance, one respondent stated that MGUS patients represent 'a hugely neglected cohort of patients from a nursing input' and that patients could benefit from access to a patient-friendly information leaflet.

\section{Discussion}

The findings of this study suggest that while the majority of MGUS patients are informed of their diagnosis, there may be situations where haematology healthcare professionals decide that 
alternative terminology is necessary. Age, education and cognitive ability were cited as the main reasons for withholding information about the condition and/or the risk of progression to myeloma and associated malignancies. The findings of this study have implications for patients and healthcare professionals alike.

The main strength of our study was that we were able to capture the views of a range of healthcare professionals within haematology from two different healthcare systems. As a region of the United Kingdom, Northern Ireland uses the National Healthcare System (NHS) which provides free healthcare for all. In contrast, the Republic of Ireland currently operates a two-tier healthcare system which affords preferential access to those with private health insurance (approximately $45 \%$ of the population)(23). Despite these differences, similar responses to the survey were expressed by healthcare professionals in both countries suggesting our findings may be generalizable to other regions. Within this survey, the majority of respondents supported frequent review of MGUS patients with follow-up of low risk patients within primary care/community settings. Outreach haematology services for MGUS patients, involving specialist nurse-led community monitoring programmes, have been shown to be effective and improve patient satisfaction in the UK(24). However, while transferring/sharing of services between primary and secondary care may reduce haematology service burden, the economic impact to patients by replacing free outpatient visits, as provided in the Republic of Ireland, with costly GP visits for those $<70$ years of age who are not eligible for free primary care visits(23) should not be overlooked.

Despite advocating for MGUS follow-up within primary care, several respondents reported a general lack of awareness and knowledge of MGUS by healthcare providers outside haematology. As MGUS review moves increasingly towards primary care, the challenge is for haematology specialists to work alongside GPs to ensure appropriate care pathways, adhering to the published guidelines are in 
place (25-27). Development of standardised discharge letters for MGUS patients with clear instructions on follow-up procedures and symptoms/signs of progression for primary care providers warrants further assessment.

Several respondents highlighted that the detection of a paraprotein can lead to unnecessary stress and anxiety in patients. While several studies have reported increased anxiety and distress in patients with premalignant conditions $(28,29)$, lack of appropriate information at diagnosis and follow-up is consistently reported $(13,18,19)$. Provision of an information leaflet at the point of diagnosis is recommended by the UK Myeloma Forum and Nordic Myeloma Study Group(26) and may help reduce psychological distress experienced by patients(30). However, within the present study, just over $40 \%$ of respondents reported providing all of their MGUS patients with an information leaflet despite acknowledging that patients are often confused by their diagnosis and are generally not well-informed. Many respondents cited that information leaflets were not available to them and highlighted the need for development of an appropriate information leaflet. Currently, MGUS patient information leaflets are freely available on the internet from cancer charity websites including Myeloma UK and Macmillan. It is important that all healthcare professionals are made aware of these underutilised resources and that arrangements are put in place to make these valuable resources available to patients. While restricting the survey to attendees of the Haematology Association of Ireland meeting may have limited the generalisability of the findings, it is still the largest haematology meeting on the island of Ireland and attended by a wide spectrum of healthcare professionals with different roles and experience.

In conclusion, this survey of haematology healthcare professionals has highlighted a number of important issues for patients and healthcare professionals. Moving forward, it is imperative that 
guidelines are developed to assist healthcare professionals outside haematology, particularly GPs, in managing MGUS patients. 


\section{Funding}

This work was supported by Cancer Research UK Population Science Postdoctoral Research Fellowship (Dr Charlene McShane; C51094/A18267).

\section{Acknowledgements}

The authors would like to take this opportunity to thank the organisers of the Haematology Association of Ireland 2016 meeting and the conference delegates for participating in this study.

\section{Authorship roles}

The idea and design for this project was developed and led by CMcS and LAA. All members of the study team participated in the distribution and collection of surveys. CMcS analysed the data. CMcS wrote the first draft of the manuscript. All authors reviewed and provided feedback on the final version of the manuscript. 


\section{References}

1. Landgren $\mathrm{O}$, Weiss BM. Patterns of monoclonal gammopathy of undetermined significance and multiple myeloma in various ethnic/racial groups: support for genetic factors in pathogenesis. Leukemia. 2009; 9;23(10):1691-7.

2. Weiss BM, Abadie J, Verma P, Howard RS, Kuehl WM. A monoclonal gammopathy precedes multiple myeloma in most patients . Blood. 2009;113(22):5418-22.

3. Cancer Research United Kingdom (CRUK). Myeloma statistics [Internet]. Available from: http://www.cancerresearchuk.org/cancer-info/cancerstats/types/myeloma/

4. Kyle RA, Durie BGM, Rajkumar SV, Landgren O, Blade J, Merlini G, et al. Monoclonal gammopathy of undetermined significance (MGUS) and smoldering (asymptomatic) multiple myeloma: IMWG consensus perspectives risk factors for progression and guidelines for monitoring and management. Leukemia. 2010;24(6):1121-7.

5. Kyle RA, Therneau TM, Rajkumar SV, Offord JR, Larson DR, Plevak MF, et al. A Long-Term Study of Prognosis in Monoclonal Gammopathy of Undetermined Significance. N Engl J Med. 2002;346(8):564-9.

6. Kyle R, Buadi F, Rajkumar S. Management of monoclonal gammopathy of undetermined significance (MGUS) and smoldering multiple myeloma (SMM). Oncol. 2011;25(7):578-86.

7. Turesson I, Kovalchik S, Pfeiffer R. Monoclonal gammopathy of undetermined significance and risk of lymphoid and myeloid malignancies: 728 cases followed up to 30 years in Sweden. Blood. 2014;123(3):338-46.

8. Melton LJ, Rajkumar SV, Khosla S, Achenbach SJ, Oberg AL, Kyle R a. Fracture risk in monoclonal gammopathy of undetermined significance. J Bone Miner Res. 2004;19(1):25-30.

9. Sallah S, Husain a, Wan J, Vos P, Nguyen NP. The risk of venous thromboembolic disease in 
patients with monoclonal gammopathy of undetermined significance. Ann Oncol. 2004;15(10):1490-4.

10. Kristinsson SY, Fears TR, Gridley G, Turesson I, Mellqvist U-H, Björkholm M, et al. Deep vein thrombosis after monoclonal gammopathy of undetermined significance and multiple myeloma. Blood. 2008;112(9):3582-6.

11. Srkalovic G, Cameron MG, Rybicki L, Deitcher SR, Kattke-Marchant K, Hussein M a. Monoclonal gammopathy of undetermined significance and multiple myeloma are associated with an increased incidence of venothromboembolic disease. Cancer. 2004;101(3):558-66.

12. Berenson JR, Anderson KC, Audell R a, Boccia R V, Coleman M, Dimopoulos $\mathrm{M}$ a, et al. Monoclonal gammopathy of undetermined significance: a consensus statement. $\mathrm{Br} \mathrm{J}$ Haematol. 2010;150(1):28-38.

13. Kennedy F, Harcourt D, Rumsey N. The challenge of being diagnosed and treated for ductal carcinoma in situ (DCIS). Eur J Oncol Nurs. 2008;12(2):103-11.

14. Kennedy F, Harcourt D, Rumsey N. Perceptions of ductal carcinoma in situ (DCIS) among UK health professionals. The Breast. 2009;18(2):89-93.

15. Partridge A, Winer JP, Golshan M, Bellon JR, Blood E, Dees EC, et al. Perceptions and Management Approaches of Physicians Who Care for Women with Ductal Carcinoma In Situ. Clin Breast Cancer. 2008;8(3):275-80.

16. Griffiths H, Davies R. Understanding Barrett's columnar lined oesophagus from the patients' perspective: qualitative analysis of semistructured interviews with patients. Front Gastroenterol . 2011; 2(3): 168-175

17. Prinjha S, Evans J, McPherson A. Women's information needs about ductal carcinoma in situ before mammographic screening and after diagnosis: a qualitative study. J Med Screen. 2006;13(3):110-4. 
18. Prinjha S, Evans J, McPherson A. Women's information needs about ductal carcinoma in situ before mammographic screening and after diagnosis: a qualitative study. J Med Screen. 2006;13(3):110-4.

19. Bluman LG, Borstelmann NA, Rimer BK, Iglehart JD, Winer EP. Knowledge, Satisfaction, and Perceived Cancer Risk among Women Diagnosed with Ductal Carcinoma In Situ. J Womens Health Gend Based Med. 2001;10(6):589-98.

20. Rood JA, Eeltink CM, van Zuuren FJ, Verdonck-de Leeuw IM, Huijgens PC. Perceived need for information of patients with haematological malignancies: a literature review. J Clin Nurs. 2014;24:353-69.

21. De Morgan SE, Butow PN, Lobb EA, Price MA, Nehill C. Development and pilot testing of a communication aid to assist clinicians to communicate with women diagnosed with ductal carcinoma in situ (DCIS). Support Care Cancer. 2011;19(5):717-23.

22. O'Cathain A, Thomas KJ. "Any other comments?" Open questions on questionnaires - a bane or a bonus to research? BMC Med Res Methodol. BioMed Central; 2004;4:25.

23. Burke SA, Normand C, Barry S, Thomas S. From universal health insurance to universal healthcare? The shifting health policy landscape in Ireland since the economic crisis. Health Policy. 2016;120(3):235-40.

24. Rawstron AC, Jones RA, Ferguson C, Hughes G, Selby P, Reid C, et al. Outreach monitoring service for patients with indolent B-cell and plasma cell disorders: a UK experience. Br J Haematol. 2007 Dec;139(5):845-8.

25. The International Myeloma Working Group. Criteria for the classification of monoclonal gammopathies, multiple myeloma and related disorders: a report of the International Myeloma Working Group. Br J Haematol. 2003 Jun;121(5):749-57.

26. Bird J, Behrens J, Westin J, Turesson I, Drayson M, Beetham R, et al. UK Myeloma Forum 
(UKMF) and Nordic Myeloma Study Group (NMSG): guidelines for the investigation of newly detected M-proteins and the management of monoclonal gammopathy of undetermined significance (MGUS). Br J Haematol. 2009 Oct;147(1):22-42.

27. van de Donk NWCJ, Palumbo A, Johnsen HE, Engelhardt M, Gay F, Gregersen H, et al. The clinical relevance and management of monoclonal gammopathy of undetermined significance and related disorders: recommendations from the European Myeloma Network. Haematologica. 2014 Jun;99(6):984-96.

28. Tiersma ESM, van der Lee ML, Garssen B, Peters AAW, Visser AP, Fleuren GJ, et al. Psychosocial factors and the course of cervical intra-epithelial neoplasia: A prospective study. Gynecol Oncol. 2005 Jun;97(3):879-86.

29. Kennedy F, Harcourt D, Rumsey N, White P. The psychosocial impact of ductal carcinoma in situ (DCIS): A longitudinal prospective study. The Breast. 2010 Oct;19(5):382-7.

30. Stav K, Siegel YI, Beberashvili I, Sella HZ, Zisman A. Provision of information leaflet before urodynamic study reduces the pre-examination anxiety level. Neurourol Urodyn. 2016 Sep;35(7):805-8. 
Table 1. Summary of survey responses

\begin{tabular}{|c|c|c|c|c|}
\hline & $\begin{array}{c}\text { All } \\
\text { respondents } \\
(n=55)\end{array}$ & $\begin{array}{l}\text { Rep. of Ireland } \\
\text { respondents } \\
(n=41)\end{array}$ & $\begin{array}{l}\text { Northern Ireland } \\
\text { respondents } \\
(n=13)\end{array}$ & p-value \\
\hline $\begin{array}{l}\text { Job } \\
\text { Consultant } \\
\text { Registrar } \\
\text { Foundation doctor } \\
\text { Specialist Nurse } \\
\text { Nurse } \\
\text { Allied Healthcare professional } \\
\text { Other }\end{array}$ & $\begin{array}{c}16(29.1) \\
12(21.8) \\
4(7.3) \\
12(21.8) \\
9(16.4) \\
1(1.8) \\
1(1.8) \\
\end{array}$ & $\begin{array}{c}13(31.7) \\
11(26.8) \\
4(9.8) \\
9(22) \\
3(7.3) \\
1(2.4) \\
0 \\
\end{array}$ & $\begin{array}{c}3(23.1) \\
1(7.7) \\
0 \\
3(23.1) \\
6(46.2) \\
0 \\
0 \\
\end{array}$ & 0.04 \\
\hline $\begin{array}{l}\text { Frequency } \\
\text { Daily } \\
\text { Weekly } \\
\text { Monthly } \\
\text { Never } \\
\text { Prefer not to say } \\
\end{array}$ & $\begin{array}{l}7(12.7) \\
27(49.1) \\
12(21.8) \\
6(10.9) \\
3(5.5) \\
\end{array}$ & $\begin{array}{c}6(14.6) \\
22(53.7) \\
7(17.1) \\
4(9.8) \\
2(4.9) \\
\end{array}$ & $\begin{array}{l}1(7.7) \\
5(38.5) \\
4(30.8) \\
2(15.4) \\
1(7.7) \\
\end{array}$ & 0.66 \\
\hline $\begin{array}{l}\text { Number of patients } \\
0-50 \\
51-100 \\
101-200 \\
201+ \\
\text { Prefer not to say/missing }\end{array}$ & $\begin{array}{c}23(41.8) \\
14(25.5) \\
5(9.1) \\
4(7.3) \\
9(16.4)\end{array}$ & $\begin{array}{c}16(39) \\
13(31.7) \\
4(9.8) \\
3(7.3) \\
5(12.2)\end{array}$ & $\begin{array}{l}7(53.9) \\
1(7.7) \\
1(7.7) \\
1(7.7) \\
3(23.1)\end{array}$ & 0.39 \\
\hline $\begin{array}{l}\text { Do you tell patients they have } \\
\text { MGUS? } \\
\text { Yes, all patients } \\
\text { Yes, some patients } \\
\text { No } \\
\text { Missing/other }\end{array}$ & $\begin{array}{l}38(69.1) \\
9(16.4) \\
6(10.9) \\
2(3.6) \\
\end{array}$ & $\begin{array}{c}31(75.6) \\
6(14.6) \\
3(7.3) \\
1(2.4) \\
\end{array}$ & $\begin{array}{l}7(53.9) \\
2(15.4) \\
3(23.1) \\
1(7.7) \\
\end{array}$ & 0.20 \\
\hline $\begin{array}{l}\text { Do you tell MGUS patients about } \\
\text { risk of progression? } \\
\text { Yes, all patients } \\
\text { Yes, some patients } \\
\text { No } \\
\text { Missing/other }\end{array}$ & $\begin{array}{c}38(69.1) \\
9(16.4) \\
7(12.7) \\
1(1.8)\end{array}$ & $\begin{array}{c}29(70.7) \\
8(19.5) \\
4(9.8) \\
0 \\
\end{array}$ & $\begin{array}{c}8(61.5) \\
1(7.7) \\
3(23.1) \\
1(7.7) \\
\end{array}$ & 0.15 \\
\hline $\begin{array}{l}\text { Do you give MGUS patients } \\
\text { information leaflet? } \\
\text { Yes, all the time } \\
\text { Only if the patient asks } \\
\text { Never } \\
\text { Missing/other }\end{array}$ & $\begin{array}{c}23(41.8) \\
15(27.3) \\
13(23.6) \\
4(7.3)\end{array}$ & $\begin{array}{c}16(39) \\
13(31.7) \\
9(22) \\
3(7.3)\end{array}$ & $\begin{array}{l}7(53.8) \\
1(7.7) \\
4(30.8) \\
1(7.7)\end{array}$ & 0.32 \\
\hline $\begin{array}{l}\text { Do you recommend that MGUS } \\
\text { patients are followed-up?* } \\
\text { Yes, all MGUS patients should be } \\
\text { followed up frequently } \\
\text { Yes, but only MGUS patients } \\
\text { deemed to be at intermediate/high } \\
\text { risk of progressing } \\
\text { Yes, but followed-up in primary care } \\
\text { No } \\
\text { Missing/other }\end{array}$ & $\begin{array}{l}28(50.9) \\
17(30.9)\end{array}$ & $\begin{array}{c}23(56.1) \\
12(29.3) \\
\\
10(24.4) \\
0 \\
0 \\
\end{array}$ & $\begin{array}{l}5(38.5) \\
5(38.5) \\
\\
3(23.1) \\
3(23.1) \\
0 \\
\end{array}$ & 0.04 \\
\hline
\end{tabular}

* Numbers do not equal to $100 \%$ as respondents ticked multiple options which have been counted separately 
Table 2. Examples of responses to open-ended survey questions

\begin{tabular}{|c|c|}
\hline Question & Selection of respondent answers* \\
\hline $\begin{array}{l}\text { How do you describe MGUS to } \\
\text { your patients? }\end{array}$ & $\begin{array}{l}\text { - You have some cells in your blood which are making a little } \\
\text { too much protein. This will probably not cause you any } \\
\text { harm but you need to be followed up long-term. } \\
\text { (Consultant) } \\
\text { - Abnormal protein, not cancer. Followed-up in case it } \\
\text { changes and causes symptoms needing treatment. If [you] } \\
\text { develop new symptoms, knowing protein present may } \\
\text { speed diagnosis. (Consultant) } \\
\text { - I tell some patients it is not a disease but a "pre-disease" } \\
\text { state. (Consultant) } \\
\text { - A protein that you don't need and in some people can } \\
\text { progress into a disease that causes harm but is treatable. } \\
\text { (Consultant) } \\
\text { - I sometimes explain to patients that finding a paraprotein } \\
\text { is a bit like finding a 'lump' and needing to investigate } \\
\text { further whether benign or malignant - generally patients } \\
\text { find this concept easier to understand. (Consultant) } \\
\text { - An abnormal protein that in most people needs just } \\
\text { watching but can start to cause damage and develop into a } \\
\text { blood cancer "like a mole we need to watch". (Registrar) } \\
\text { - A sleeping condition that may or may not ever cause any } \\
\text { problems/progress to myeloma. (Nurse) }\end{array}$ \\
\hline $\begin{array}{l}\text { Do you tell patients that they } \\
\text { have 'MGUS' or 'monoclonal } \\
\text { gammopathy of } \\
\text { undetermined/uncertain } \\
\text { signficiance'? }\end{array}$ & $\begin{array}{l}\text { - I believe most patients want to know and take some } \\
\text { ownership. Also it allows patients to educate themselves. } \\
\text { (Consultant) } \\
\text { - Not all patients have cognitive ability to retain complex } \\
\text { info. Some families will request limited information. Other } \\
\text { impending clinical concerns may preclude disclosure. } \\
\text { (Foundation Doctor) } \\
\text { - When reviewing pts I would use both of above [terms: } \\
\text { MGUS and monoclonal gammopathy of undetermined } \\
\text { significance] initially but then would break down and use } \\
\text { words like 'blood problem', 'high level of protein' etc. } \\
\text { (Foundation Doctor) } \\
\text { I usually say "abnormal protein" which comes with a long } \\
\text { name "monoclonal gammopathy". I sometimes write the } \\
\text { name down. I don't emphasise the name. (Other) }\end{array}$ \\
\hline $\begin{array}{l}\text { Do you tell patients about the } \\
\text { associated risk of progression } \\
\text { to a haematological } \\
\text { malignancy? }\end{array}$ & $\begin{array}{l}\text { - Less than I probably should. (Consultant) } \\
\text {-.. 10\% risk. Don't tend to say cancer or malignancy, tend } \\
\text { to say "Blood Condition" or if they push it I might say "a } \\
\text { type of blood cancer". (Consultant) } \\
\text { - Explain small risk of progression to a malignant disease } \\
\text { multiple myeloma. They will look up on internet + find out } \\
\text { or better to tell and in most cases say risk is low. } \\
\text { (Consultant) } \\
\text { - As part of the explanation as to why we or the GP needs to } \\
\text { monitor them (Consultant) }\end{array}$ \\
\hline
\end{tabular}




\begin{tabular}{|c|c|}
\hline & $\begin{array}{l}\text { - All patients should be aware of the possibility of } \\
\text { progression that would mean beginning of treatment and } \\
\text { not just wait and watch. (Consultant) } \\
\text { - Explain the small risk of progression to symptomatic } \\
\text { myeloma per year. (Registrar) } \\
\text { - This will promote further understanding and acceptance of } \\
\text { disease if were to happen in future. (Registrar) } \\
\text { - [Responding to why they only tell some patients] Some } \\
\text { elderly patients- who may become very anxious and find } \\
\text { this risk quite distressing. (Specialist Nurse) }\end{array}$ \\
\hline $\begin{array}{l}\text { Do you recommend follow-up } \\
\text { of patients? }\end{array}$ & $\begin{array}{l}\text { Depending on co-morbidities, haematology follow-up may } \\
\text { not be needed - but annual FBC + MGUS assessment is } \\
\text { reasonable - sometimes in primary care. (Consultant) } \\
\text { - We see them yearly in clinic; ideally could be nurse led. } \\
\text { (Registrar) } \\
\text { - Can generally be f/u in primary care - unless free light } \\
\text { chains only, high risk of progression, anxious patient/GP or } \\
\text { complicating factors e.g. renal failure of other aetiology. } \\
\text { (Registrar) } \\
\text { - Frequency of attending hospital should be determined by } \\
\text { stratified risk - high risk --> hospital; telephone } \\
\text { clinic/community - intermediate/low. (Specialist Nurse) } \\
\text { - Frequency of follow up determined by risk group for each } \\
\text { patient. Limited resource for follow up in primary care. } \\
\text { (Specialist Nurse) } \\
\text { Clinic appointments create unnecessary stress to well } \\
\text { patients (Nurse) }\end{array}$ \\
\hline
\end{tabular}

*Quotes are displayed as presented within returned surveys unless the study team felt context was needed as indicated by [context]. 